\title{
PROBING BEHAVIOUR OF PASSION VINE HOPPER ON SELECTED HOST PLANTS
}

\author{
M. SANDANAYAKA ${ }^{1}$ and D.P. LOGAN ${ }^{2}$ \\ ${ }^{1}$ HortResearch, Private Bag 92169, Auckland \\ ${ }^{2}$ HortResearch, No.1 Road, RD 2, Te Puke \\ Corresponding author: msandanayaka@hortresearch.co.nz
}

The passion vine hopper Scolypopa australis Walker (Homoptera: Ricaniidae) is an introduced pest of kiwifruit and feeds on a wide range of plants. The preference of fifthinstar nymphs for mahoe (Melicytus ramiflorus), Canadian fleabane (Conyza canadensis), kiwifruit (Actinidia chinensis) and kawakawa (Macropiper excelsum) was tested in cages in a shade house under choice conditions and in the laboratory using the Electrical Penetration Graph (EPG) technique. EPG measures the stylet pathway of probing insects. In this study, EPG was used to monitor the total probing time and the number of probes of the nymphs for 12 hours on each host plant. A total of 13-17 nymphs per host were monitored using a single nymph per plant. Mahoe was the most preferred and kawakawa was the least preferred host in both choice and EPG tests. Fleabane was less preferred than kiwifruit in choice tests, but there was no difference in total probing time and number of probes between kiwifruit and fleabane in EPG tests.

\section{SUPPRESSION OF BOTRYTIS CINEREA SPORULATION ON STRAWBERRY LEAVES}

\author{
S. CARD ${ }^{1}$, M.V. JASPERS ${ }^{1}$, M. WALTER ${ }^{2}$, A. SZTEJNBERG ${ }^{3}$ \\ and A. STEWART ${ }^{1}$
}
${ }^{1}$ The National Centre for Advanced Bio-Protection Technologies, P.O. Box 84, Lincoln University, Canterbury, New Zealand
${ }^{2}$ HortResearch, PO Box 51, Lincoln, Canterbury, New Zealand
${ }^{3}$ Faculty of Agricultural, Food and Environmental Quality Sciences, The Hebrew University of Jerusalem, Rehovot 76100, Israel

Corresponding author: cards@lincoln.ac.nz

The ability of endemic New Zealand isolates, Trichoderma atroviride (LU132), Epicoccum purpurascens (LU148) and fluorescent Pseudomonas spp. (LU1001, LU1002, LU1003 and LU1004), to suppress Botrytis cinerea sporulation on whole strawberry plants was compared to the efficacy of the commercial biocontrol product, Prestop ${ }^{\mathrm{TM}}$, and the new botryticide, Teldor $500 \mathrm{SC}^{\mathrm{TM}}$. The foliage of strawberry plants (cv. Aptos) grown at $18^{\circ} \mathrm{C}, 85-95 \%$ relative humidity and 12 hour photoperiod was inoculated with spray suspensions of test isolates $\left(10^{7}\right.$ fungal spores $/ \mathrm{ml}$ or $10^{8}$ bacterial $\left.\mathrm{cfu} / \mathrm{ml}\right)$ and challenged after 24 hours with a spray suspension of the pathogen $\left(10^{5}\right.$ conidia $\left./ \mathrm{ml}\right)$. After a further 24 hours, leaf discs were cut from treated plants and placed on herbicideamended agar, which promoted leaf senescence and facilitated $B$. cinerea development. Pathogen sporulation was quantified 7 days later by estimating the proportion of leaf disc covered by B. cinerea conidiophores. The chemical fungicide, Teldor $500 \mathrm{SC}^{\mathrm{TM}}$, completely inhibited $B$. cinerea development. The most successful isolate, T. atroviride (LU132), significantly $(\mathrm{P}<0.05)$ suppressed sporulation compared to the pathogen-only control by up to $80 \%$, equal to that of the commercial biocontrol product Prestop ${ }^{\mathrm{TM}}$. The other isolates were less effective than T. atroviride (LU132) with suppression of pathogen sporulation ranging from $0-46 \%$. 